\title{
EHMTI-0281. Frequency of headache in stroke
}

\author{
N Zaric ${ }^{*}$, N Milovanovic-Kovacevic, M Savic \\ From 4th European Headache and Migraine Trust International Congress: EHMTIC 2014 \\ Copenhagen, Denmark. 18-21 September 2014
}

\section{Background}

Headache is a relatively common symptom associated with various types of stroke. It belongs to symptomatic headaches and is classifed in the 6th group IHS classification.

The aim of this study was to compare the frequency of the headache in stroke patients depending on sex, age, type of stroke, duration of headache, location and size of the cerebral lesion.

\section{Methods}

From January 1 to December 31,2013. 5,476 stroke patients were admitted in St. Sava hospital. Out of them, 843 patients were treated, female 402, male 441, mean age 67,9 . The patients were studied using the standard protocol including CT and MR. The presence of headache was established by taking history from the patients or relatives.

\section{Results}

Among these patients, $48.9 \%$ had experienced headache, with higher frequency in female $(64.3 \%)$, less than 70 years old. Frequency of headache in patients with ischemia was $41.6 \%$, and with hemorrhage $50.3 \%$. Headache was most common in patients with cortical lesions $(56.7 \%)$ and with lesions located in the basilar artery (41.3\%). Large lesions $(>2 \mathrm{~cm})$ were more frequently followed with headache (62.3\% vs. $28 \%)$. The average duration of headache in ischaemic stroke was 25 hours compared to 65 hours in haemorrhagic stroke.

\section{Conclusions}

Headache was more frequent in females $(\mathrm{P}<0,01)$, in patients with hemorrhage $(\mathrm{P}<0,05)$, with large ischemic lesions $(\mathrm{P}<0,01)$, located in the basilar distribution $(\mathrm{P}<$ $0,05)$ and in the cortical area $(\mathrm{P}<0,05)$.

No conflict of interest.

Neurosonology, Hospital for Cerebrovascular Diseases Sveti Sava, Belgrade, Serbia

(c) 2014 Zaric et al; licensee Springer. This is an Open Access article distributed under the terms of the Creative Commons Attribution License (http://creativecommons.org/licenses/by/2.0), which permits unrestricted use, distribution, and reproduction in any medium, provided the original work is properly cited.
Published: 18 September 2014

doi:10.1186/1129-2377-15-S1-C66

Cite this article as: Zaric et al.: EHMTI-0281. Frequency of headache in stroke. The Journal of Headache and Pain 2014 15(Suppl 1):C66.

Submit your manuscript to a SpringerOpen ${ }^{\circ}$ journal and benefit from:

- Convenient online submission

- Rigorous peer review

- Immediate publication on acceptance

- Open access: articles freely available online

- High visibility within the field

- Retaining the copyright to your article

Submit your next manuscript at $\gg$ springeropen.com 